\title{
Surface-erosion behaviour of biopolymer-treated soils assessed by EFA
}

\author{
YEONG-MAN KWON*, SOO-MIN HAM†, TAE-HYUK KWON†, GYE-CHUN CHO§ and ILHAN CHANG\|
}

\begin{abstract}
Exocultured biopolymers are ecofriendly soil-stabilisation agents with superior particle bonding, hydrogel-formation characteristics and zero endoculture duration. However, the use of exocultured biopolymers for enhancing soil resistance against surface erosion by water flow is yet to be investigated. Using erosion function apparatus (EFA) in combination with an ultrasonic P-wave reflection monitoring device, the effect of exocultured biopolymers on the erosion parameters of critical shear stress and the erodibility coefficient was examined in this study in soils with different particle distributions. In this way, biopolymer soil treatment showed a ten-fold increase in critical shear stress along with a $90 \%$ reduction in erodibility coefficient; results which could be attributed to enhanced particle-to-particle contact and increased pore-fluid viscosity and pore clogging. The results of this study demonstrate the feasibility of using exocultured biopolymers in mitigating surface erosion of erosion-prone soils.
\end{abstract}

KEYWORDS: erosion; ground improvement; soil stabilisation

Published with permission by the ICE under the CC-BY 4.0 license. (http://creativecommons.org/licenses/by/4.0/)

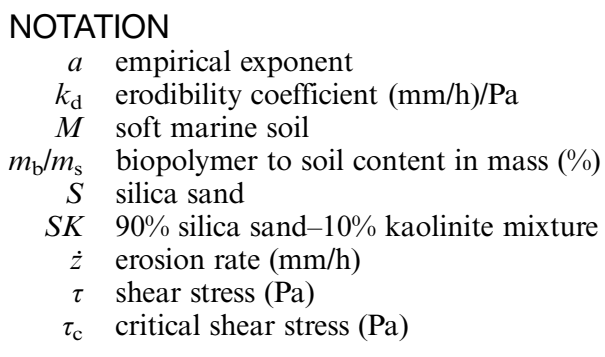

\section{INTRODUCTION}

Soil scouring and erosion induced by flowing water tend to alter the stability of geotechnical engineering structures (Shirole \& Holt, 1991; Pagán-Ortiz, 1998; Briaud et al., 2001). In general, methods employed for the prevention and/or minimisation of such scouring include bed armouring (Lauchlan \& Melville, 2001; Dey \& Raikar, 2007), flow alteration (Zarrati et al., 2006; Deng \& Cai, 2010; Heidarpour et al., 2010) and chemical soil stabilisation (Bahar et al., 2004; Cheng \& Cord-Ruwisch, 2012).

Recently, microbial biopolymers have been introduced to enhance geotechnical properties such as compressive

Manuscript received 22 July 2019; first decision 11 October 2019; accepted 11 October 2019.

Published online at www.geotechniqueletters.com on 20 December 2019.

*Department of Civil and Environmental Engineering, Korea Advanced Institute of Science and Technology, Daejeon, Republic of Korea (Orcid:0000-0002-4719-1241).

$\dagger$ Department of Civil and Environmental Engineering, Korea Advanced Institute of Science and Technology, Daejeon, Republic of Korea (Orcid:0000-0001-6940-0414).

tDepartment of Civil and Environmental Engineering, Korea Advanced Institute of Science and Technology, Daejeon, Republic of Korea (Orcid:0000-0002-1610-8281).

$\S$ Department of Civil and Environmental Engineering, Korea Advanced Institute of Science and Technology, Daejeon, Republic of Korea (Orcid:0000-0001-8582-9237).

॥School of Engineering and Information Technology, University of New South Wales (UNSW), Canberra, Australia (Orcid:0000-0001-8369-0606).
(Chang \& Cho, 2012; Chang et al., 2015a, 2015b) or shear strengths (Nugent et al., 2010; Lee et al., 2017, 2019; Chang \& Cho, 2019; Kwon et al., 2019) and/or reducing the hydraulic conductivity of soils (Bouazza et al., 2009; Wiszniewski \& Cabalar, 2014; Chang et al., 2016a; Kim et al., 2019). Compared to endocultured biopolymers, exocultured biopolymer soil treatment (BST) offers several benefits in terms of quantity, quality control and immediate soil stabilisation (Chang et al., 2016b, 2018). However, while endocultured biopolymers have demonstrated a capacity for enhancing erosion resistance (Ham et al., 2016, 2018), the erosion behaviour of exocultured biopolymer-treated soil (BPTS) remains poorly understood.

To address this, the current study investigates the effects of two exocultured biopolymers - xanthan gum (XG) and starch - on the erosion resistance of soils. Despite XG provides lower erosion resistance improvement than guar gum (Nugent et al., 2010), XG is more economically feasible due to its microbial producibility (Chang et al., 2016b). In-laboratory experiments were performed using erosion function apparatus (EFA) in combination with P-wave reflection monitoring. Soil erosion rates were measured under different shear stresses, and the erosion parameters of critical shear stress and erodibility coefficient were evaluated.

\section{MATERIALS AND METHODS Materials}

Soil samples. The soil samples used in this study were variously constituted of silica sand (Pyungchang, Korea), kaolinite clay (Bintang, Indonesia) and soft marine soil (Yeosu, Korea). Figure 1 depicts the particle-size distribution, particle shape and basic properties - Atterberg limits, specific gravity and soil type - of the soils according to ASTM D 2216-10 (ASTM, 2010), D 6913/D 6913M-17 (ASTM, 2017a), D 854-14 (ASTM, 2014) and D 7928-17 (ASTM, 2017b).

Biopolymers. $\mathrm{XG}$ is a polysaccharide biopolymer found in the bacterial species Xanthomonas campestris. It is capable of strengthening soils by way of inter-particle bonding (Chang et al., 2015a), and it can also facilitate permeability 


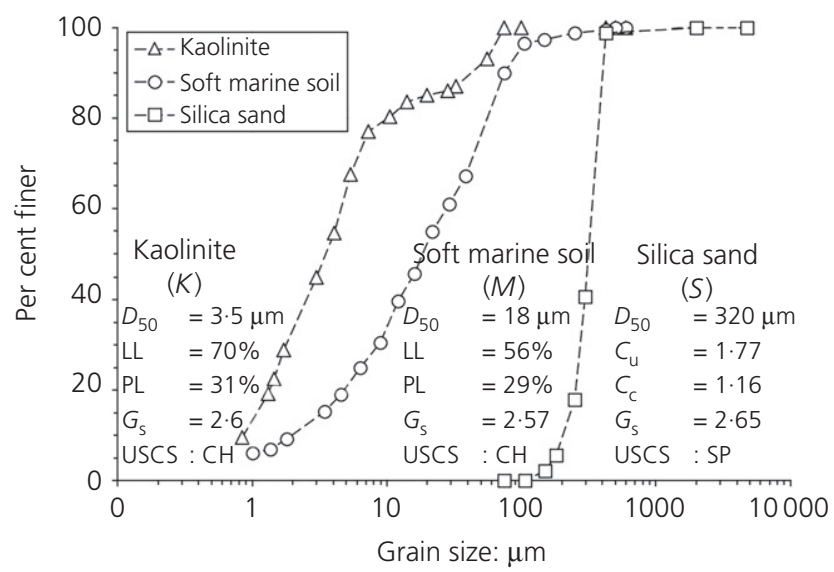

(a)

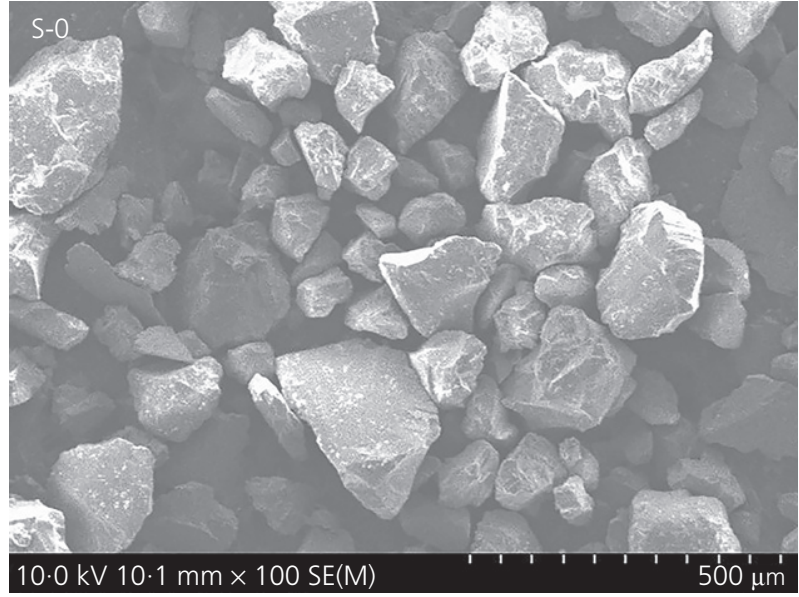

(b)

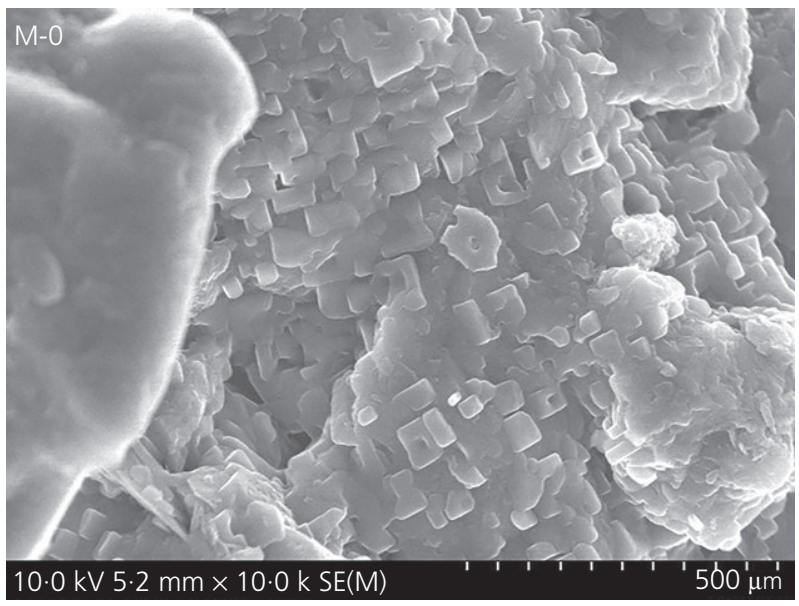

(d)

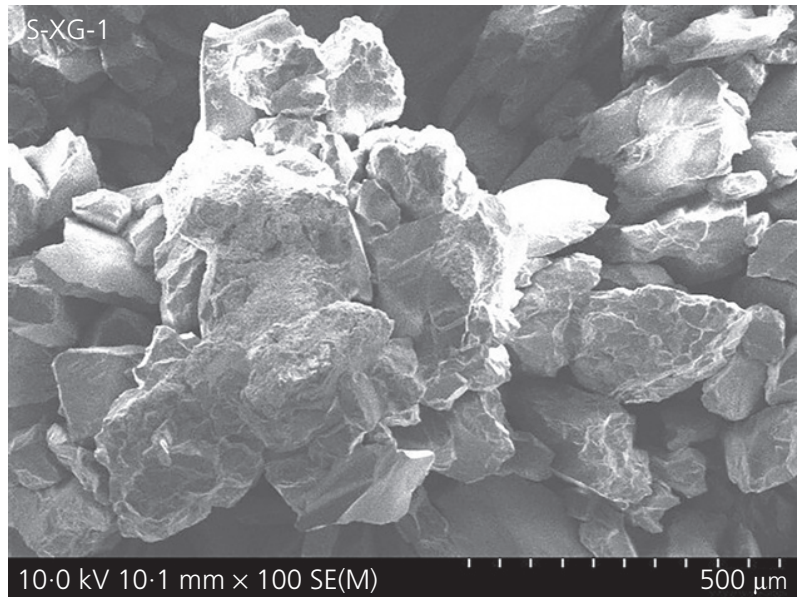

(c)

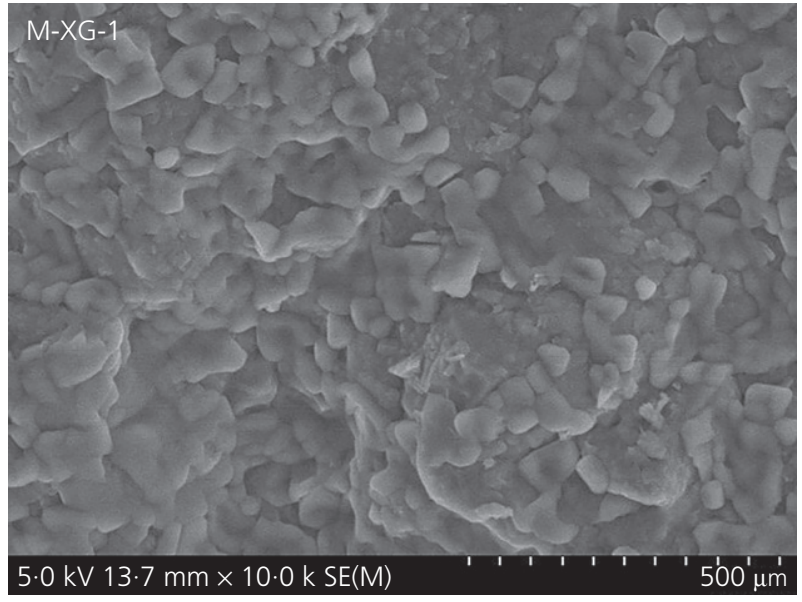

(e)

Fig. 1. Soils used in this study: (a) Particle-size distribution curve of silica sand, kaolinite and soft marine soils. SEM images of (b) untreated silica sand; (c) 1\%-XG-treated silica sand; (d) untreated soft marine soil; and (e) 1\%-XG-treated soft marine soil. USCS, Unified Soil Classification System

control through pore clogging (Ayeldeen et al., 2016). Research-grade XG (Sigma Aldrich, CAS: 11138-66-2) was used in this study.

Starch, a biopolymer originating in plants such as potato, maize and cassava, is common and economically viable (López et al., 2004; Jose \& Carvalho, 2011). In geotechnical engineering applications, starch has been used to realise soil strength and viscosity control of drilling fluids (Chang et al., 2016b). Research-grade corn starch (Sigma Aldrich, CAS: 9005-25-8) was used in this study.
Mixing starch with XG serves to enhance the viscosity and stability of starch gels (Shalviri et al., 2010). As such, an $\mathrm{XG}$-starch mixture with mass ratio of $3: 7$ (XS) was adopted. The results obtained were compared with pure XG-treated conditions.

\section{Experimental methods}

Sample preparation. Three soil types were considered in this study: silica sand (S); $90 \%$ silica sand with $10 \%$ 
kaolinite (SK); and soft marine soil (M). All soil samples were washed and dried for $24 \mathrm{~h}$ in an oven at $110^{\circ} \mathrm{C}$ (ASTM, 2010). The dry soils and two biopolymer solutions were thoroughly mixed with controlled water content to obtain uniform BPTS samples with intended biopolymer content $\left(m_{\mathrm{b}} / m_{\mathrm{s}}\right)$. Details of specimen preparation conditions, $m_{\mathrm{b}} / m_{\mathrm{s}}$ and sample identifiers are summarised in Table 1.

Table 1. Description of soil specimens

\begin{tabular}{|c|c|c|c|c|c|c|}
\hline Soil & Treatment & $m_{\mathrm{b}} / m_{\mathrm{s}}: \%$ & Water content: $\%$ & Symbol & Void ratio & Relative compaction: $\%$ \\
\hline \multirow[t]{3}{*}{ Silica sand } & Untreated & 0 & 30 & $\mathrm{~S}-0$ & $0 \cdot 89$ & 86 \\
\hline & XG & 1 & 30 & S-XG-1 & $0 \cdot 90$ & 88 \\
\hline & $\mathrm{XS}(30: 70)$ & 1 & 30 & S-XS-1 & $0 \cdot 90$ & 85 \\
\hline Silica sand $(90 \%)$-kaolinite $(10 \%)$ & Untreated & 0 & 30 & SK-0 & $0 \cdot 85$ & 85 \\
\hline \multirow[t]{3}{*}{ Soft marine soil } & Untreated & 0 & 50 & $\mathrm{M}-0$ & $1 \cdot 49$ & 84 \\
\hline & $\mathrm{XG}$ & 1 & 50 & M-XG-1 & $1 \cdot 62$ & 80 \\
\hline & $\mathrm{XG}$ & 2 & 50 & M-XG-2 & $1 \cdot 58$ & 81 \\
\hline
\end{tabular}

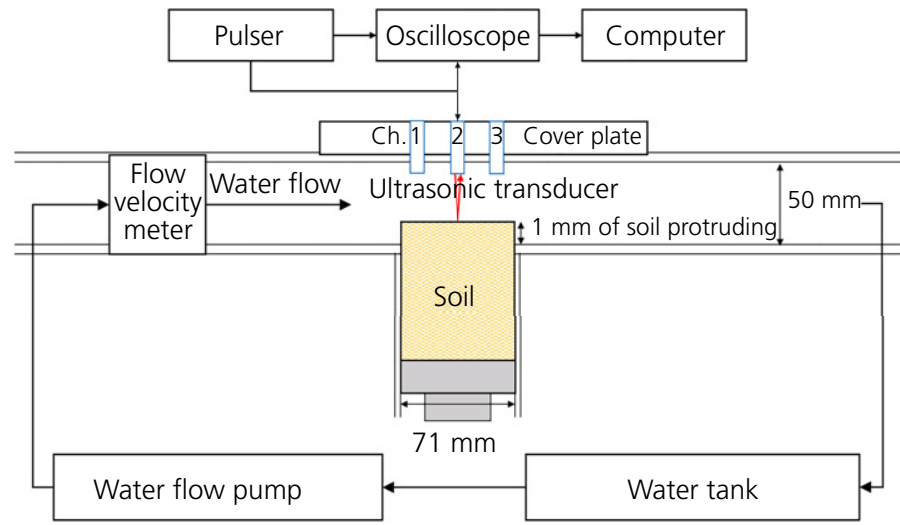

(a)

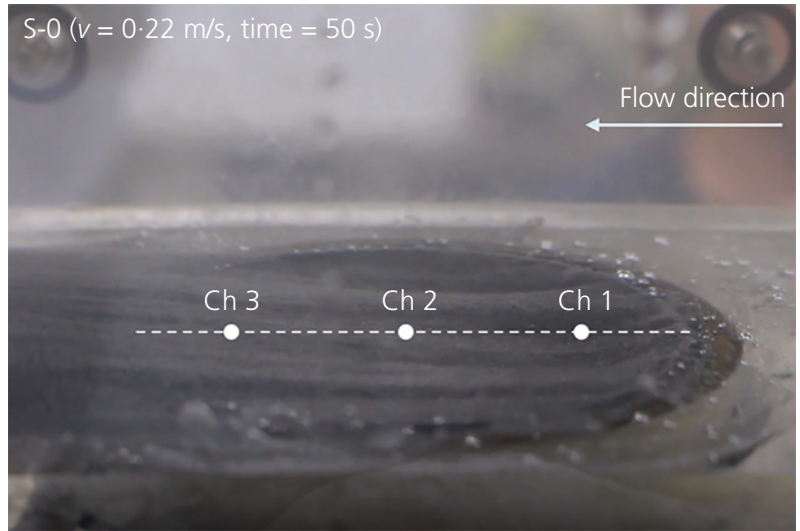

(b)

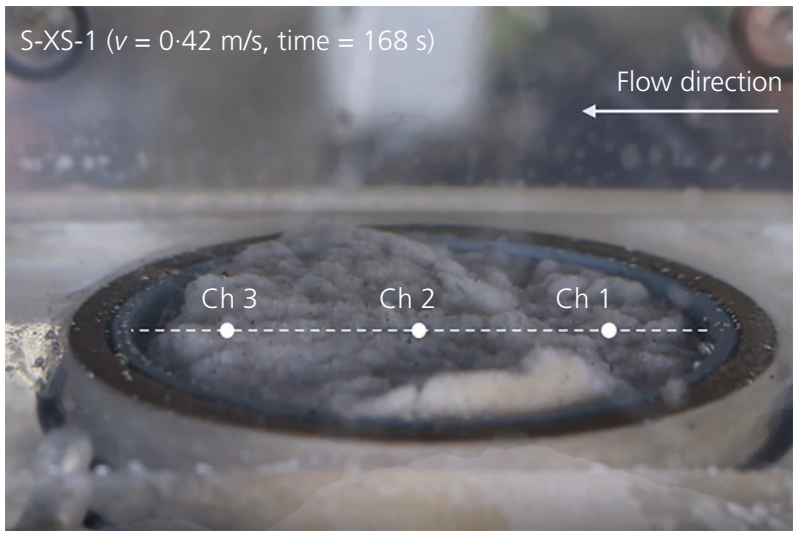

(d)

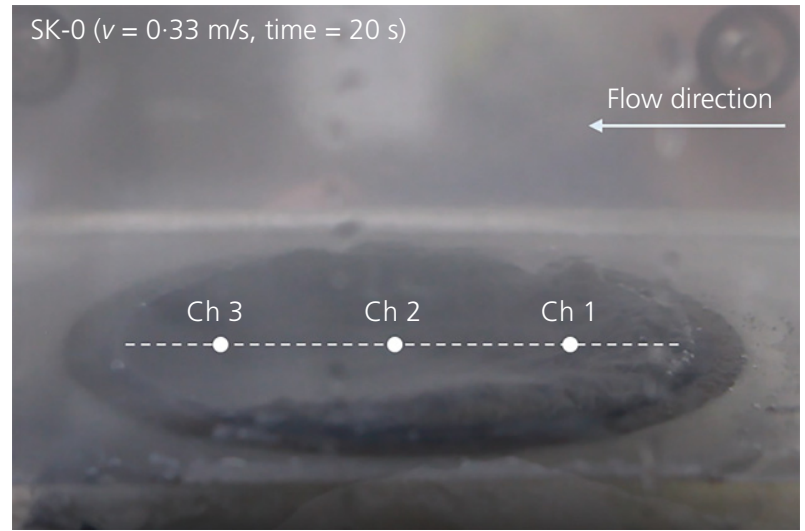

(c)

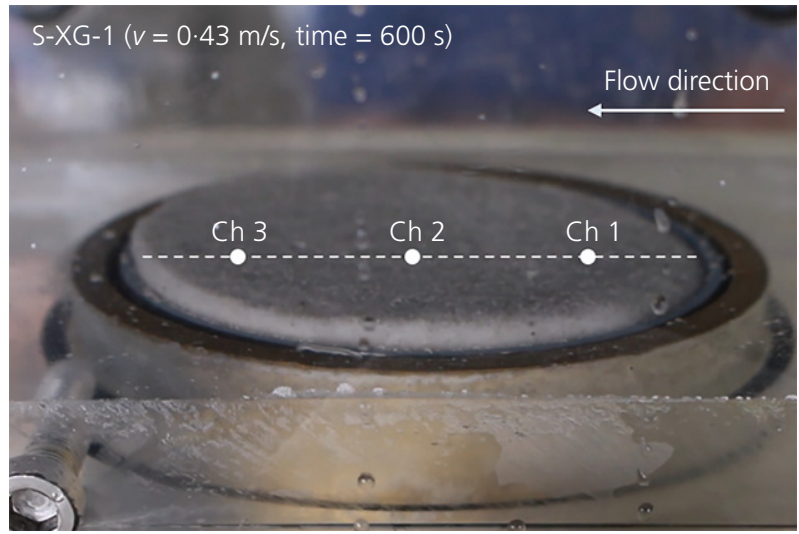

(e)

Fig. 2. Details of (a) the testing apparatus and result of EFA experiments for (b) untreated silica sand (S-0); (c) untreated silica sand-kaolinite mixture (SK-0); (d) 1\% XS-treated silica sand (S-XS-1) and (e) $1 \%$ XG- treated silica sand (S-XG-1). Ch, channel 
The soil mixtures were hand-tamped into thin-walled tubes that measured $300 \mathrm{~mm}$ long and with external and internal diameters of 76.2 and $71 \mathrm{~mm}$, respectively. Soil columns of $200 \mathrm{~mm}$ (Ham et al., 2016) were thus formed, and both ends of the tube were sealed with paraffin (Parafilm M, Sigma Aldrich, Inc.) to prevent water evaporation prior to loading for erosion testing.

Scouring tests. The soil erosion rates at various flow velocities were monitored using an ultrasonic P-wave reflection monitoring system installed on EFA (Ham et al., 2016). The samples were placed inside the EFA and then subjected to water flowing at velocities ranging from $0 \cdot 1$ to $1.75 \mathrm{~m} / \mathrm{s}$. Once steady flow had been established and the soils fully saturated, each soil column was pushed upwards by pneumatic piston to protrude by $1 \mathrm{~mm}$ into the flowing water (Briaud et al., 2001).

The eroded depth over time of soil was monitored using three pairs of ultrasonic transducers (VP-3, CTS Valpey Co.) to acquire P-waves reflecting from the sample surface (Ham et al., 2016). Figure 2 depicts the untreated soil (a, b) and BPTS (c, d) results, demonstrating uneven surface erosion and emphasising the need for multi-channel monitoring. The time required to erode $1 \mathrm{~mm}$ of soil protruding from the tube was obtained by averaging the times recorded at three locations along the flow direction. To ensure repeatability, three identical specimens were prepared and tested under identical conditions. The results of $\mathrm{P}$-wave monitoring demonstrated a significant increase in erosion depth with increased flow velocity, whereas reduced erosion was observed in the presence of clay and in biopolymer-treated silica sand (Fig. 3). Test results were compared with the erosion behaviour of dextran (produced by Leuconostoc mesenteroides)-treated sand which has been assessed using the same EFA as this study (Ham et al., 2018).

\section{EXPERIMENTAL RESULTS}

\section{Variations in erosion rate with changes in water flow}

Figure 4 depicts changes in the $\dot{z}$ of the soil samples against flow velocity. For the untreated soils (S-0, SK-0 and M-0), the $\dot{z}$ was observed to reduce with the increase in the proportion of fine particles due to the enhanced electrostatic attraction between them so that S- $0<\mathrm{SK}-0<\mathrm{M}-0$ in terms of $\dot{z}$. This enhanced electrostatic attraction also served to improve resistance against flow-induced shear forces, a finding that agrees with studies by Briaud et al. (1999) and Ham et al. (2016). In addition, regardless of soil type, BST caused a reduction in the rate of soil erosion. The S-XG-1 and S-XS-1 soils were seen to withstand water flow longer than SK-0, implying that even minimal biopolymer treatment (e.g. $1 \%$ mass fraction) is sufficient to induce significant improvement in the erosion resistance of sand. Realisation of lower or even equivalent erosion mitigation using clay treatment would require an in-soil clay concentration of more than $10 \%$.

\section{Effect of biopolymers on erosion curve}

The $\dot{z}$ and erosion resistance of soils can be expressed in terms of shear stress $(\tau)$ caused by flowing water at the soil-water interface, and this stress can be calculated as a function of flow velocity (e.g. Reynolds number) and soil-surface roughness (Moody, 1944; Briaud et al., 1999, 2001). In this study, the relationship between $\dot{z}$ and $\tau$ was modelled in terms of critical $\left(\tau_{\mathrm{c}}\right)$ and excess shear stresses (Hanson \& Cook, 2004; Wan \& Fell, 2004; Daly et al., 2013; Khanal et al., 2016) as

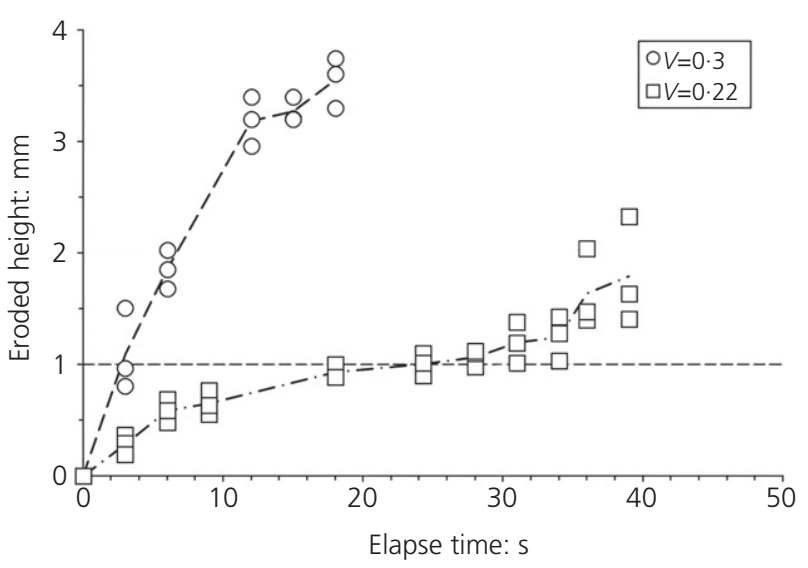

(a)

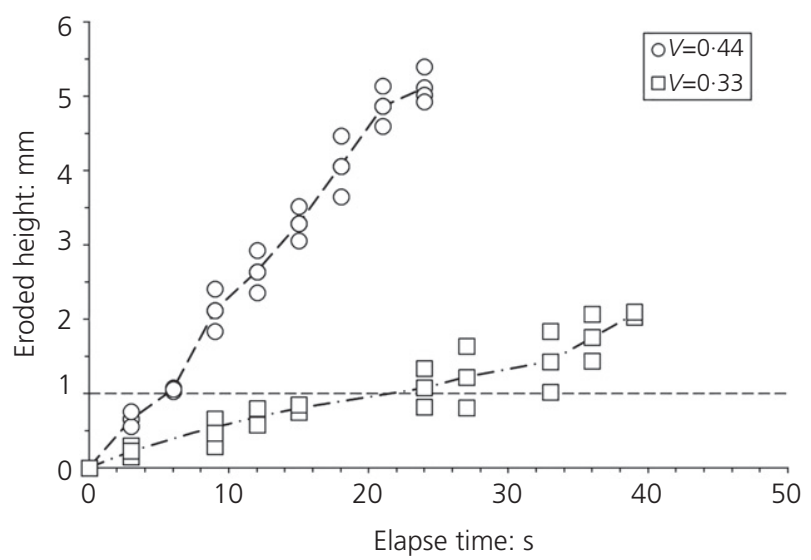

(b)

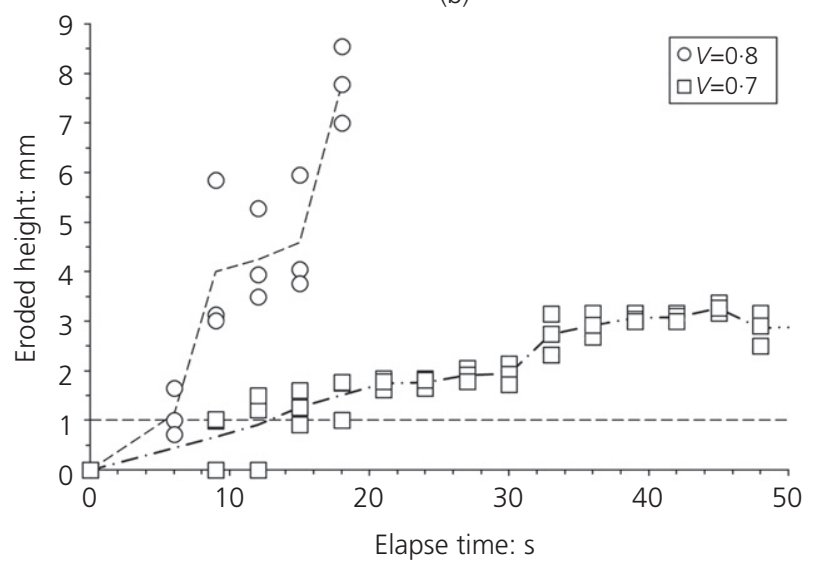

(c)

Fig. 3. Ultrasonic reflection monitoring results of $S-0, S K-0$ and S-XG-1 soils eroded at various flow velocities $(0.22-0.8 \mathrm{~m} / \mathrm{s})$ by EFA testing

$$
\dot{z}=k_{\mathrm{d}}\left(\tau-\tau_{\mathrm{c}}\right)^{\mathrm{a}}
$$

where $k_{\mathrm{d}}$ denotes the erodibility coefficient $(\mathrm{mm} / \mathrm{h} \mathrm{Pa})$, indicating the sensitivity of $\dot{z}$ to excess shear stress (Ham et al., 2016), and $\tau_{\mathrm{c}}$ denotes the critical shear stress (Pa) under which soil erosion from flowing water commences (Briaud et al., 1999). The value of the empirical power exponent $(a)$ was determined to be 1 , and this finding was in agreement with extant studies (Hanson \& Cook, 2004; Midgley et al., 2012; Al-Madhhachi et al., 2013).

Figure 5 depicts erosion $(\dot{z}-\tau)$ curves corresponding to all untreated and the treated $\mathrm{S}$ and $\mathrm{M}$ soils. The higher the fine-particle content in untreated soils (Fig. 5(a)), the higher the erosion resistance (Briaud et al., 1999, 2001; 


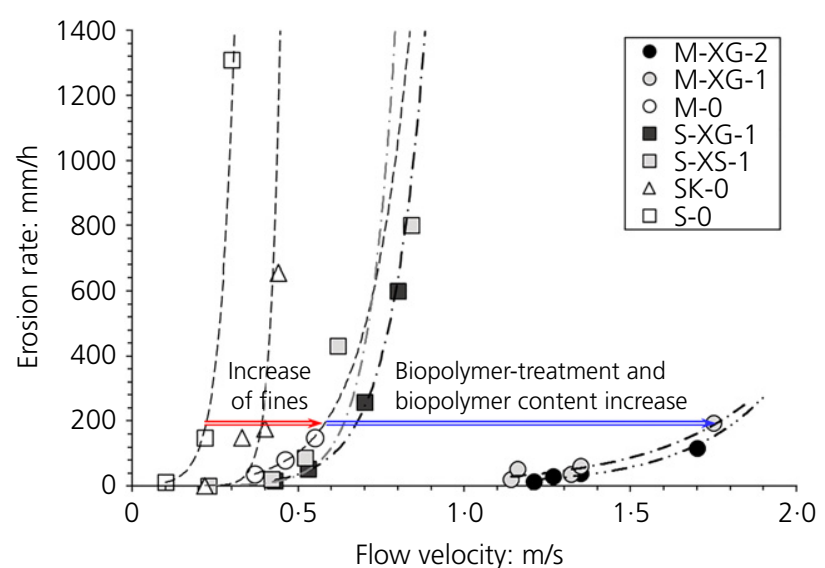

Fig. 4. Erosion rate against flow velocity

Wan \& Fell, 2004; Briaud, 2008; Ham et al., 2016) which can, as before, be attributed to the electrostatic attraction exerted by the increasing numbers of clay particles (Simon \& Collison, 2001; Julian \& Torres, 2006). Furthermore, the value of $\tau_{\mathrm{c}}$ increases from 0.08 to $0.29 \mathrm{~Pa}$ in the order of S- $0<$ SK- $0<\mathrm{M}-0$, and soil composition was also observed to affect soil erodibility leading to a reduction in $k_{\mathrm{d}}$ values with the increase in fine particles following an S-0 $>$ SK-0 $>$ M-0 pattern (Table 2).

The BST demonstrated significant enhancement of the erosion resistance of the $\mathrm{S}$ and $\mathrm{M}$ soils (Table 2; Figs 5(b) and 5(c)). Although endocultured 0.4\% dextran (Ham et al., 2018) demonstrated similar resistance to that of the SK soil (Fig. 5(b)), the exocultured BSTs with $1 \% \mathrm{XG}$ and $1 \% \mathrm{XS}$ in this study demonstrated a significant increase in the $\tau_{\mathrm{c}}$ of $\mathrm{S}$ soils up to $0.75 \mathrm{~Pa}(\mathrm{~S}-\mathrm{XG}-1)$, as well as reducing $k_{\mathrm{d}}$ from 4465.6 to $379.9 \mathrm{~mm} / \mathrm{h} \mathrm{Pa}$ in the $\mathrm{S}-0$ and $\mathrm{S}-\mathrm{XG}-1$ samples, respectively.

Compared to the $\mathrm{S}$ soil results, the erosion curves of the treated $\mathrm{M}$ samples indicate an even more dramatic improvement in erosion resistance (Fig. 5(c)) which could presumably be due to electrostatic interactions between clay particles and the biopolymers (Chang et al., 2019). Specifically, XG treatment was observed to enhance the $\tau_{\mathrm{c}}$ value in the $\mathrm{M}$ soils from $0.29 \mathrm{~Pa}(\mathrm{M}-0)$ to $2.99 \mathrm{~Pa}$ (M-XG-2) while decreasing the corresponding $k_{\mathrm{d}}$ values from $252.6 \mathrm{~mm} / \mathrm{h}$ Pa for M-0 to $36.9 \mathrm{~mm} / \mathrm{h}$ Pa for M-XG-2 (Table 2). However, M-XG-2 only showed a minor increase of erosion resistance compared to $\mathrm{M}-\mathrm{XG}-1$ indicating that a biopolymer content of $1 \%$ is sufficient to mitigate erosion of the $\mathrm{M}$ soil.

\section{Possible biopolymer mechanisms impacting erosion behaviour of soils}

The results of this study show that adding the biopolymers $\mathrm{XG}$ and XS to soils enhances their erosion resistance. This can be explained in terms of three possible mechanisms pertaining to particle contact and pore space: First, including biopolymers affects the bonding characteristics of soil grains because biopolymers tend to coat and bridge soil particles by way of electrical bonding (Chang et al., 2019; Renault et al., 2009) and/or biofilm formation (Khatami \& O'Kelly, 2012; Chang et al., 2015a, 2016a). As a result, the number of shear stress cycles required to break contact between soil particles increases during BST (Briaud et al., 1999, 2001). Second, biopolymers adsorb water and form hydrogels, thereby increasing pore-fluid viscosity (Matsuoka et al., 1997; García-Ochoa et al., 2000), and

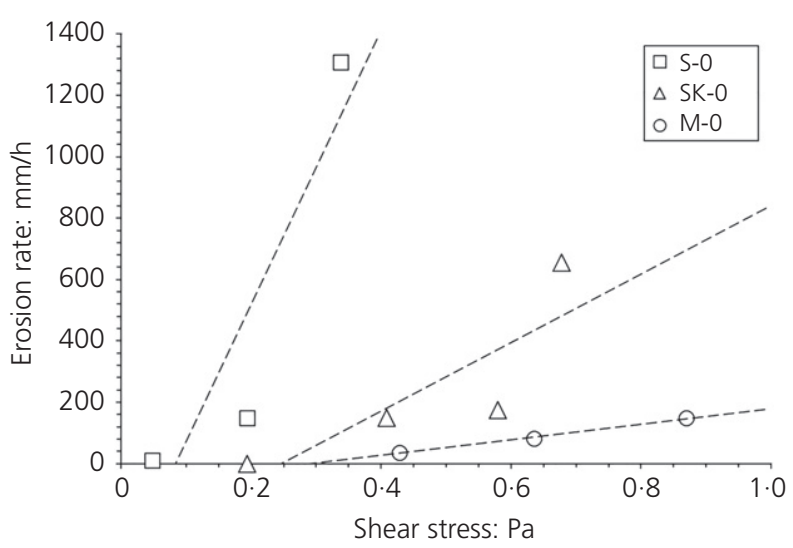

(a)

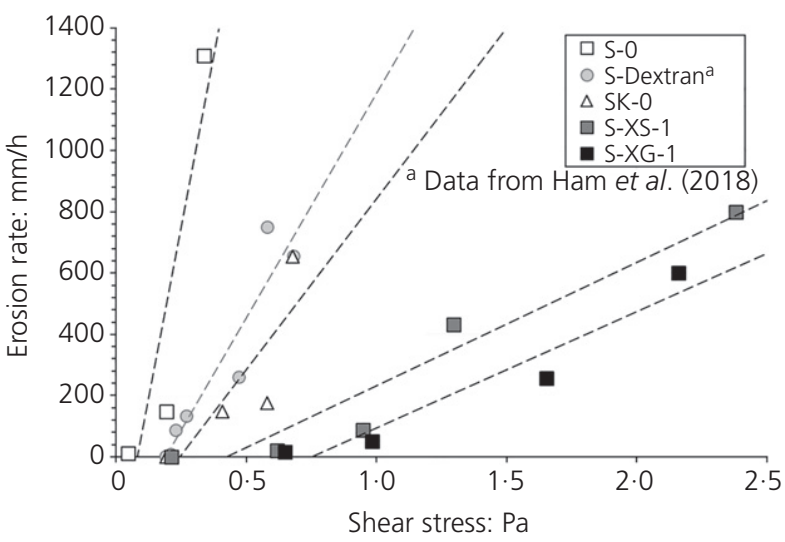

(b)

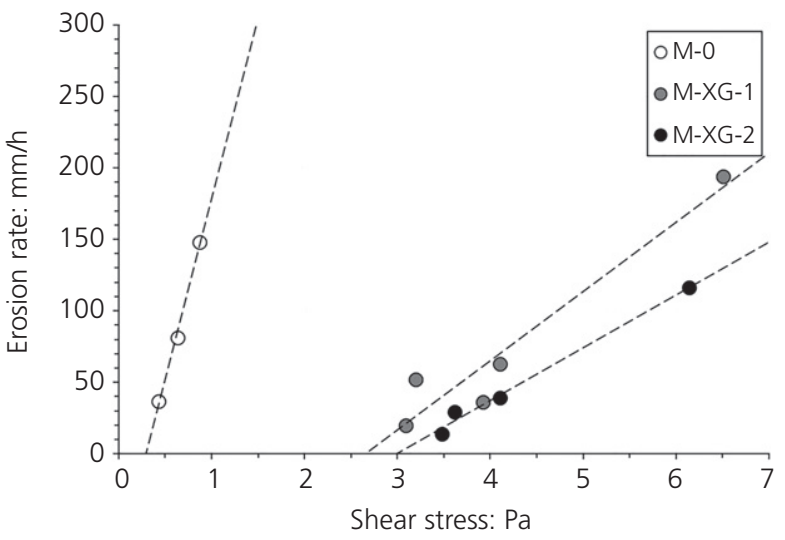

(c)

Fig. 5. Erosion curves of the tested soils: (a) untreated soils; (b) treated silica sands and (c) treated soft marine soils

this water-adsorbing characteristic increases soil shear strength (Nugent et al., 2009) and resistance to water flow (Briaud et al., 2001). Finally, biopolymer-associated hydrogels reduce soil permeability and cause pore clogging (Martin et al., 1996), which leads to a reduction in seepage flow and surface erosion (Ham et al., 2018). The combined effect of these phenomena is that the addition of biopolymers serves to increase the shear stress $\left(\tau_{\mathrm{c}}\right)$ at which erosion occurs while also reducing the amount of erosion due to water flow $\left(k_{\mathrm{d}}\right)$ (Table 2 and Fig. 5).

BPTS strength gradually reduces with cyclical wetting and drying processes (Chang et al., 2017). This study was conducted in fully saturated conditions, but matric suction in unsaturated conditions may further enhance the erosion resistance of soils (Shaikh et al., 1988; Vanapalli et al., 1996). Thus, it is recommended that the long-term durability of 
Table 2. EFA test results

\begin{tabular}{|c|c|c|c|c|c|c|}
\hline Soil & BST condition & Symbol & Fine content: $\%$ & $m_{\mathrm{b}} / m_{\mathrm{s}}: \%$ & $k_{\mathrm{d}}: \mathrm{mm} / \mathrm{h}$ & $\tau_{\mathrm{c}}: \mathrm{Pa}$ \\
\hline $\begin{array}{l}\text { Silica sand } \\
\text { Soft marine soil }\end{array}$ & $\begin{array}{l}\text { Untreated } \\
\text { Kaolinite }(10 \%) \\
\text { Dextran }(0 \cdot 4 \%)^{*} \\
\text { XS }(1 \%) \\
\text { XG }(1 \%) \\
\text { Untreated } \\
\text { XG }(1 \%) \\
\text { XG }(2 \%)\end{array}$ & $\begin{array}{l}\text { S-0 } \\
\text { SK-0 } \\
\text { S-Dextran } \\
\text { S-XS-1 } \\
\text { S-XG-1 } \\
\text { M-0 } \\
\text { M-XG-1 } \\
\text { M-XG-2 }\end{array}$ & $\begin{array}{r}0 \\
10 \\
0 \\
0 \\
0 \\
95 \\
95 \\
95\end{array}$ & $\begin{array}{l}0 \\
0 \\
0 \cdot 4 \\
1 \\
1 \\
0 \\
1 \\
2\end{array}$ & $\begin{array}{r}4465 \cdot 6 \\
1116 \cdot 2 \\
1464 \cdot 8 \\
403 \cdot 0 \\
379 \cdot 9 \\
252 \cdot 6 \\
48 \cdot 5 \\
36 \cdot 9\end{array}$ & $\begin{array}{l}0 \cdot 08 \\
0 \cdot 25 \\
0 \cdot 19 \\
0 \cdot 43 \\
0 \cdot 75 \\
0 \cdot 29 \\
2 \cdot 65 \\
2 \cdot 99\end{array}$ \\
\hline
\end{tabular}

*Data from Ham et al. (2018).

BPTS and the effects of unsaturated conditions are considered in further studies.

\section{CONCLUSIONS}

This study demonstrates the effects of exocultured biopolymer treatment on the erosion resistance of soils and confirms that their addition improves erosion resistance by enhancing interparticle bonding, increasing fluid viscosity, and inducing greater pore clogging. The addition of a small amount of biopolymer ( $\sim 1 \%$ aggregate mass) facilitates higher erosion resistance than other treatments, for example, the addition of kaolinite (which may require up to $10 \%$ aggregate mass) or endocultured dextran. This demonstrates the potential of exocultured biopolymer treatments for improving the erosion resistance of different soils. In future work, variations in the erosion parameters - critical shear stress and erodibility coefficient - will be quantified in terms of biopolymer type and content, and the physico-chemical characteristics of soils. Indeed, the long-term durability of BPTS must be verified under severe climatic variation to ensure its in situ performance and stability.

\section{ACKNOWLEDGEMENTS}

The authors acknowledge the Water Management Research Program funded by the Ministry of Land, Infrastructure and Transport (MOLIT) of the Korean government (19AWMPB114119-04) and the National Research Foundation of Korea (NRF) grant funded by the Korean government (MSIP) (2017R1A2B4008635), which collectively funded this project.

\section{REFERENCES}

Al-Madhhachi, A. S. T., Hanson, G. J., Fox, G. A., Tyagi, A. K. \& Bulut, R. (2013). Measuring soil erodibility using a laboratory 'Mini' JET. Trans. ASABE 56, No. 3, 901-910.

ASTM (2010). D 2216-10: standard test methods for laboratory determination of water (moisture) content of soil and rock by mass. ASTM International, West Conshohocken, PA, USA.

ASTM (2014). D 854-14: standard test methods for specific gravity of soil solids by water pycnometer. ASTM International, West Conshohocken, PA, USA.

ASTM (2017a). D 6913/D6913M-17: standard test methods for particle-size distribution (gradation) of soils using sieve analysis. ASTM International, West Conshohocken, PA, USA.

ASTM (2017b). D 7928-17: standard test method for particle-size distribution (gradation) of fine-grained soils using the sedimentation (hydrometer) analysis. ASTM International, West Conshohocken, PA, USA

Ayeldeen, M. K., Negm, A. M. \& El Sawwaf, M. A. (2016). Evaluating the physical characteristics of biopolymer/soil mixtures. Arab. J. Geosci. 9, No. 5, 1-13.

Bahar, R., Benazzoug, M. \& Kenai, S. (2004). Performance of compacted cement-stabilised soil. Cem. Concr. Compos. 26, No. 7, 811-820.
Bouazza, A., Gates, W. \& Ranjith, P. (2009). Hydraulic conductivity of biopolymer-treated silty sand. Géotechnique 59, No. 1, 71-72, https://doi.org/10.1680/geot.2007.00137.

Briaud, J. L. (2008). Case histories in soil and rock erosion: Woodrow Wilson bridge, Brazos river meander, Normandy cliffs, and New Orleans levees. J. Geotech. Geoenviron. Engng 134, No. 10, 1425-1447.

Briaud, J. L., Ting, F. C. K., Chen, H. C., Gudavalli, R., Perugu, S. \& Wei, G. (1999). SRICOS: prediction of scour rate in cohesive soils at bridge piers. J. Geotech. Geoenviron. Engng 125, No. 4, 237-246.

Briaud, J. L., Ting, F. C. K., Chen, H. C., Cao, Y., Han, S. W. \& Kwak, K. W. (2001). Erosion function apparatus for scour rate predictions. J. Geotech. Geoenviron. Engng 127, No. 2, 105-113.

Chang, I. \& Cho, G. C. (2012). Strengthening of Korean residual soil with $\beta-1,3 / 1,6$-glucan biopolymer. Constr. Build. Mater. 30, 30-35.

Chang, I. \& Cho, G. C. (2019). Shear strength behavior and parameters of microbial gellan gum-treated soils: from sand to clay. Acta Geotech. 14, No. 2, 361-375.

Chang, I., Im, J., Prasidhi, A. K. \& Cho, G. C. (2015a). Effects of xanthan gum biopolymer on soil strengthening. Constr. Build. Mater. 74, 65-72.

Chang, I., Prasidhi, A. K., Im, J. \& Cho, G. C. (2015b). Soil strengthening using thermo-gelation biopolymers. Constr. Build. Mater. 77, No. 0, 430-438.

Chang, I., Im, J. \& Cho, G. C. (2016a). Geotechnical engineering behaviors of gellan gum biopolymer treated sand. Can. Geotech. J. 53, No. 10, 1658-1670.

Chang, I., Im, J. \& Cho, G. C. (2016b). Introduction of microbial biopolymers in soil treatment for future environmentallyfriendly and sustainable geotechnical engineering. Sustainability 8, No. 3, 251.

Chang, I., Im, J., Lee, S. W. \& Cho, G. C. (2017). Strength durability of gellan gum biopolymer-treated Korean sand with cyclic wetting and drying. Constr. Build. Mater. 143, 210-221.

Chang, I., Im, J., Chung, M. K. \& Cho, G. C. (2018). Bovine casein as a new soil strengthening binder from dairy wastes. Constr. Build. Mater. 160, 1-9.

Chang, I., Kwon, Y. M., Im, J. \& Cho, G. C. (2019). Soil consistency and interparticle characteristics of xanthan gum biopolymercontaining soils with pore-fluid variation. Can. Geotech. J. 56, No. 8, 1206-1213.

Cheng, L. \& Cord-Ruwisch, R. (2012). In situ soil cementation with ureolytic bacteria by surface percolation. Ecol. Engng 42, 64-72.

Daly, E. R., Fox, G. A., Miller, R. B. \& Al-Madhhachi, A. S. T. (2013). A scour depth approach for deriving erodibility parameters from jet erosion tests. Trans. ASABE 56, No. 6, $1343-1351$

Deng, L. \& Cai, C. S. (2010). Bridge scour: prediction, modeling, monitoring, and countermeasures. Pract. Period. Struct. Des. Constr. 15, No. 2, 125-134.

Dey, S. \& Raikar, R. V. (2007). Clear-water scour at piers in sand beds with an armor layer of gravels. J. Hydrau. Engng 133, No. 6, 703-711.

García-Ochoa, F., Santos, V. E., Casas, J. A. \& Gómez, E. (2000). Xanthan gum: production, recovery, and properties. Biotechnol. Adv. 18, No. 7, 549-579. 
Ham, S., Kwon, T., Chang, I. \& Chung, M. (2016). Ultrasonic $\mathrm{P}$-wave reflection monitoring of soil erosion for erosion function apparatus. Geotech. Test. J. 39, No. 2, 301-314.

Ham, S. M., Chang, I., Noh, D. H., Kwon, T. H. \& Muhunthan, B. (2018). Improvement of surface erosion resistance of sand by microbial biopolymer formation. J. Geotech. Geoenviron. Engng 144, No. 7, 06018004.

Hanson, G. J. \& Cook, K. R. (2004). Apparatus, test procedures, and analytical methods to measure soil erodibility in situ. Appl. Engng Agric. 20, No. 4, 455-462.

Heidarpour, M., Afzalimehr, H. \& Izadinia, E. (2010). Reduction of local scour around bridge pier groups using collars. Int. J. Sediment Res. 25, No. 4, 411-422.

Jose, A. \& Carvalho, F. (2011). Starch as source of polymeric materials. In Biopolymers: biomedical and environmental applications (eds S. Kalia and L. Avérous), pp. 81-98. Salem, MA, USA: Wiley.

Julian, J. P. \& Torres, R. (2006). Hydraulic erosion of cohesive riverbanks. Geomorphology 76, No. 1, 193-206.

Khanal, A., Klavon, K. R., Fox, G. A. \& Daly, E. R. (2016). Comparison of linear and nonlinear models for cohesive sediment detachment: rill erosion, hole erosion test, and streambank erosion studies. J. Hydrau. Engng 142, No. 9, 04016026-1-04016026-12.

Khatami, H. \& O'Kelly, B. (2012). Improving mechanical properties of sand using biopolymers. J. Geotech. Geoenviron. Engng 139, No. 8, 1402-1406.

Kim, Y. M., Park, T. \& Kwon, T. H. (2019). Engineered bioclogging in coarse sands by using fermentation-based bacterial biopolymer formation. Geomech. Engng 17, No. 5, 485.

Kwon, Y. M., Chang, I., Lee, M. \& Cho, G. C. (2019). Geotechnical engineering behaviors of biopolymer-treated soft marine soil. Geomech. Engng 17, No. 5, 453-464.

Lauchlan, C. S. \& Melville, B. W. (2001). Riprap protection at bridge piers. J. Hydrau. Engng 127, No. 5, 412-418.

Lee, S., Chang, I., Chung, M. K., Kim, Y. \& Kee, J. (2017). Geotechnical shear behavior of xanthan gum biopolymer treated sand from direct shear testing. Geomech. Engng 12, No. 5, $831-847$.

Lee, S., Im, J., Cho, G. C. \& Chang, I. (2019). Laboratory triaxial test behavior of xanthan gum biopolymer-treated sands. Geomech. Engng 17, No. 5, 445-452.

López, A. C. B., Pereira, A. J. G. \& Junqueira, R. G. (2004). Flour mixture of rice flour, corn and cassava starch in the production of gluten-free white bread. Braz. Arch. Biol. Technol. 47, No. 1, 63-70.

Martin, G., Yen, T. \& Karimi, S. (1996). Application of biopolymer technology in silty soil matrices to form impervious barriers. In 7th Australia New Zealand conference on geomechanics. geomechanics in a changing world: conference proceedings (eds M. B. Jaksa, W. S. Kaggwa and D. A. Cameron). Adelaide, Australia: Institution of Engineers, p. 814.
Matsuoka, Y., Shindoh, T., Yakota, K. \& Kusui, S. (1997). Property of $\beta-1$, 3-glucan (curdlan) as a viscosity agent for superworkable concrete. ACI Spec. Publ. 173, 475-492.

Midgley, T. L., Fox, G. A. \& Heeren, D. M. (2012). Evaluation of the bank stability and toe erosion model (BSTEM) for predicting lateral retreat on composite streambanks. Geomorphology 145-146, 107-114.

Moody, L. F. (1944). Friction factors for pipe flow. Trans. ASME 66, 671-684.

Nugent, R., Zhang, G. \& Gambrell, R. (2009). Effect of exopolymers on the liquid limit of clays and its engineering implications. Transp. Res. Rec., J. Transp. Res. Board 2101, 34-43.

Nugent, R. A., Zhang, G. \& Gambrell, R. P. (2010). The effects of exopolymers on the erosional resistance of cohesive sediments. In Proceedings of scour and erosion (eds S. E. Burns, S. K. Bhatia, C. M. C. Avila and B. E. Hunt), pp. 162-171. San Francisco, CA, USA: American Society of Civil Engineers (ASCE).

Pagán-Ortiz, J. E. (1998). Status of the scour evaluation of bridges over waterways in the United States. In Proceedings of ASCE conf. on water resources engineering '98, Memphis, TN, USA (eds S. R. Abt, J. Young-Pezeshk and C. C. Watson). Reston, VA, USA: ASCE, pp. 2-4.

Renault, F., Sancey, B., Badot, P. M. \& Crini, G. (2009). Chitosan for coagulation/flocculation processes - an eco-friendly approach. Eur. Polym. J. 45, No. 5, 1337-1348.

Shaikh, A., Ruff, J. F. \& Abt, S. R. (1988). Erosion rate of compacted Na-montmorillonite soils. J. Geotech. Engng 114, No. 3, 296-305.

Shalviri, A., Liu, Q., Abdekhodaie, M. J. \& Wu, X. Y. (2010). Novel modified starch-xanthan gum hydrogels for controlled drug delivery: synthesis and characterization. Carbohydr. Polym. 79, No. 4, 898-907.

Shirole, A. M. \& Holt, R. C. (1991). Planning for a comprehensive bridge safety assurance program. Transp. Res. Rec. 1290, 39-50.

Simon, A. \& Collison, A. J. C. (2001). Pore-water pressure effects on the detachment of cohesive streambeds: seepage forces and matric suction. Earth Surf. Processes Landforms 26, No. 13, $1421-1442$.

Vanapalli, S. K., Fredlund, D. G., Pufahl, D. E. \& Clifton, A. W. (1996). Model for the prediction of shear strength with respect to soil suction. Can. Geotech. J. 33, No. 3, 379-392.

Wan, C. F. \& Fell, R. (2004). Investigation of rate of erosion of soils in embankment dams. J. Geotech. Geoenviron. Engng 130, No. 4, 373-380.

Wiszniewski, M. \& Cabalar, A. F. (2014). Hydraulic conductivity of a biopolymer treated sand. In New frontiers in geotechnical engineering (eds Z. Guoping and L. Zhen), pp. 19-27. Shanghai, China: American Society of Civil Engineers (ASCE).

Zarrati, A. R., Nazariha, M. \& Mashahir, M. B. (2006). Reduction of local scour in the vicinity of bridge pier groups using collars and riprap. J. Hydrau. Engng 132, No. 2, 154-162. 